\title{
The effect of sward height and season on herbage intake of dairy cows in a rotational grazing system
}

\author{
E Spörndly, E Burstedt \\ Swedish University of Agricuitural Sciences, Department of Animal Nutrition and Management, \\ Kungsängen Experimental Station, 75323 Uppsala, Sweden
}

The main objective of this study was to quantify the influence of the season (S) and sward height $(\mathrm{H})$ on the pasture organic matter intake (PI) of dairy cows in rotational grazing systems. PI was estimated using chromic oxide as a marker. Data concerning pasture growth and composition, experimental animals and weather were also registered with the objective of including these variables in statistical analysis, if they were significant, to obtain a model for estimating PI with the data collected. Data was collected during 3 years $(Y)$. The first $Y$, pastures were trimmed at different times to obtain different $\mathrm{H}$ simultaneously. This led to a major setback of pasture growth. Therefore, during $Y$ two and three, pastures were grazed when planned target $\mathrm{H}$ was obtained. As $\mathrm{H}$ increases continuously, experimental periods (exp per) were one week, with a pre-period of five days. $S$ was divided into early $S(19 / 5-$ 20/6), mid-S (21/6-31/7) and late $S(1 / 8-17 / 8)$.

The data comprises $\mathrm{PI}$ measurements on 82 dairy cows, with an average milk yield (M) of $15.6 \mathrm{~kg} /$ day and an average live weight (W) of $546 \mathrm{~kg}$. Pasture allowance was $30 \mathrm{~kg}$ dry matter (DM)/cow and day. No supplements were fed. An in vitro digestion method using rumen fluid was used to estimate metabolisable energy (ME) content and digestibility of the herbage consumed by using the regressions obtained by Lindgren (1979, Swedish Univ Agric Sci, Anim Nutr and Management, Report 45). The pasture content of ME was 11.2, 10.2 and $10.2 \mathrm{MJ} / \mathrm{kg}$ DM for early, mid- and late $S$ respectively. Fibre content (NDF) was $48.6 \%$ of DM, more than $5 \%$ lower than mid- and late S pasture. Crude protein content for all seasons was $19 \%$. H was determined daily (min. 200 readings/ha) using a rising plate meter $\left(0.3^{*} 0.3 \mathrm{~m}\right.$ with a weight of $430 \mathrm{~g}$ ). Average $\mathrm{H}$ over all experimental period was $15.0 \mathrm{~cm}$ (range 7.421.2). The final statistical model was the following

$$
\begin{aligned}
& P I=\mu+\alpha_{i}+\gamma_{j}+B_{i j} H_{i j k}+B_{2} W_{i j k}+B_{3} M_{i j k}+e_{i j k} \\
& \mathrm{R}^{2} \text { adjusted }=0.49 \\
& i=1 \ldots 3 S ; j=1 \ldots 3 Y ; \alpha=f i x S ; \gamma=f i x Y \text {; } \\
& B_{t i}=\text { regression of } \mathrm{Pl} \text { on } \mathrm{H} \text { for } \mathrm{S} i \text {; } \\
& B_{2}=\text { regression of } \mathrm{PI} \text { on } \mathrm{W} \text {; } \\
& B_{3}=\text { regression of } \mathrm{PI} \text { on } \mathrm{M}
\end{aligned}
$$

The effect of $\mathrm{H}$ on $\mathrm{PI}$ depended on $\mathrm{S}$, giving different slopes for each $S$. The influence of $H$ on PI was significant only in early $\mathrm{S}$ where $\mathrm{PI}$ increased with $0.7 \mathrm{~kg}$ organic matter per $\mathrm{cm}$ increase in $\mathrm{H}$. Least square means for $\mathrm{Pl}$ was $12.3,13.4$ and 10.8 for early, mid- and late $S$ respectively. The influence of $\mathrm{W}$ and $\mathrm{M}$ on $\mathrm{PI}$ was 0.01 and $0.2 \mathrm{~kg} \mathrm{OM}$ per $\mathrm{kg} W$ and $M$, respectively, over all $\mathrm{S}$.

In conclusion, sward height had a large influence on the pasture intake early in the season. The high PI at high $\mathrm{H}$ is most likely due to the high content of ME, and the low fibre content of the early S pasture. The low PI at low $\mathrm{H}$ may be due to adaptation to pasture after pasture let-out, as $\mathrm{H}$ in early season is partly confounded with time after let-out. In mid- and late S PI was not influenced by $\mathrm{H}$. The low $\mathrm{PI}$ in late $\mathrm{S}$ may be partly due to dung pats from earlier rotations, making the pasture less attractive for the animal to consume (Wilkins and Garwood, 1986, Grazing, ed J Frame, BSG occ symp, $\left.n^{\circ} 19\right)$. 